\title{
STUDI FENOMENOLOGI PENGALAMAN PENYESUAIAN DIRI MAHASISWA PAPUA DI SURABAYA
}

\author{
Eri Wijanarko dan Muhammad Syafiq \\ Program studi Psikologi Universitas Negeri Surabaya \\ E-mail:eri_wija90@yahoo.co.id; syafiq_muh@yahoo.com
}

\begin{abstract}
This study was aimed to explore the Papua students' adaptation experience while they are studying in Surabaya. A qualitative approach with phenomenological method was applied. Seven participants were recruited using purposive and snowball sampling. Data collected using semi-structural interviews and analysed using interpretative phenomenological analysis (IPA). The results shows that Papua students face many difficulties in adapting to the local society. The difference in physical characteristics, language and cultural habit are the main reasons. These difficulties affect their personal and sosial life. At personal level, inferiority and sensitivity are the main issues, while at the social level, passivity and enclave formation are dominant tendencies. In order to solve the difficulties and its effects, participants apply some strategies, namely avoidance, self control, and active coping. These strategies are chosen by participants to gain self development and wellbeing. It can be concluded from the result that most partisipants are facing adaptation difficulties while they are studying in Surabaya; however, they make some efforts to cope the difficulties.
\end{abstract}

Keywords: Self-adaptation, adaptation difficulties, coping strategies.

\begin{abstract}
Abstrak: Penelitian ini bertujuan untuk mengetahui bagaimana pengalaman penyesuaian diri mahasiswa Papua di Surabaya. Pendekatan kualitatif dengan metode fenomenologis digunakan. Tujuh partisipan berhasil direkrut dengan teknik purposive dan snowball sampling. Data dikumpulkan melalui wawancara semi-terstruktur dan dianalisis menggunakan interpretative phenomenological analysis (IPA). Hasil penelitian menunjukan bahwa mahasiswa Papua di Surabaya mengalami berbagai hambatan dalam menyesuaikan diri ketika sedang menjalani kuliah. Penyebab hambatan itu adalah adalah perbedaan dalam bahasa dan kebiasaan budaya. Partisipan juga mempersepsi perbedaan fisik dan warna kulit sebagai penyebab hambatan interaksi. Hambatan interaksi yang dihadapi menimbulkan dampak personal maupun sosial bagi para partisipan. Inferioritas dan sensitifitas adalah di antara beberapa dampak personal yang dialami. Sedangkan kecenderungan untuk lebih bergaul hanya dengan sesama mahasiswa Papua dan keengganan berhubungan dekat dengan mahasiswa dan masyarakat lokal menjadi dampak sosialnya. Namun, adanya hambatan interaksi dan dampaknya tersebut disadari oleh partisipan cukup merugikan sehingga mereka menjalankan beberapa strategi penyesuaian diri untuk mengatasinya. Beberapa strategi yang dapat diidentifikasi adalah: menghindar dari masalah (avoidance), berupaya mengendalikan emosi, pikiran, dan perilaku (self control), dan menghadapi masalah secara aktif (active coping). Berbagai strategi tersebut dilakukan terutama didorong oleh dua tujuan, yaitu demi pengembangan diri dan untuk menjaga kesejahteraan psikologis mereka. Penelitian ini menyimpulkan bahwa partisipan penelitian ini menghadapi berbagai kesulitan dalam beradaptasi dengan masyarakat lokal di mana mereka sedang studi, namun mereka melakukan upaya untuk mengatasi hambatan-hambatan adaptasi tersebut.
\end{abstract}

Kata kunci: Penyesuaian diri, kesulitan penyesuaian diri, strategi coping.

Saat ini banyak mahasiswa dari luar pulau Jawa yang memilih untuk melanjutkan studi ke universitas yang ada di pulau Jawa. Pada umumnya hal ini disebabkan oleh adanya anggapan bahwa perguruan tinggi di pulau Jawa lebih memadai dari segi kualitas maupun kuantitas di banding perguruan tinggi di luar Jawa (Niam, 2009). Akhirnya muncul persepsi bahwa seseorang yang menuntut ilmu di pulau Jawa akan lebih dihargai jika 
kembali ke daerah asalnya. Menurut Pitopang (2011), banyaknya mahasiswa yang merantau ke luar daerah asalnya, terutama ke pulau Jawa, untuk kuliah juga dipengaruhi oleh harapan masyarakat asal. Jika perantau berhasil dalam menuntut ilmu lalu pulang ke kampung halaman, keluarga mereka akan bangga.

Namun, tinggal atau kuliah di tempat masyarakat yang berbeda secara sosial dan budaya kemungkinan memunculkan dampak sosial dan psikologis tertentu. Salah satu dampak sosial-psikologis yang biasa terjadi pada mereka adalah kesulitan dalam beradaptasi dengan lingkungan yang baru. Perbedaan bahasa, nilai, dan kebiasaan, di luar persoalan iklim geografis, menjadi hambatan utama.

Niam (2008) mengungkapkan bahwa kesulitan yang sering dialami mahasiswa luar Jawa saat pertama kali tinggal di pulau Jawa adalah perbedaan bahasa. Namun dalam beradaptasi tidak hanya membutuhkan kemampuan bahasa verbal. Bahasa nonverbal yang terdapat pada lingkungan baru juga sangat penting. Hal ini dikarenakan adanya perbedaan makna pada komunikasi non-verbal di setiap budaya. Sehingga jika pendatang tidak mempelajari isyarat-isyarat komunikasi non-verbal maka ada kemungkinan akan terjadi kesalahpahaman.

Dalam konteks antar negara, penelitian Sodjakusumah \& Everts (1996) terhadap mahasiswa Indonesia di New Zealand menunjukkan bahwa mereka menghadapi masalah akademis (termasuk di dalamnya perbedaan bahasa dan sistem pembelajaran), masalah sosial (tidak bisa berinteraksi dengan lingkungan sekitar), dan masalah pribadi (merasa sendiri dan rindu rumah). Kemampuan bahasa diperlukan untuk menyesuaikan diri dengan lingkungan yang asing. Apabila pendatang tidak dapat berbahasa sesuai dengan lingkungan barunya maka mereka akan merasa terisolasi.
Selain hambatan bahasa dan komunikasi, Maganga (2009) juga menyebutkan kecenderungan mahasiswa asing untuk mengelompok dengan mahasiswa dari daerah asal atau etnis yang sama sebagai hambatan adaptasi sosial. Hal ini disebabkan karena pendatang cenderung memandang kehadiran mereka bersifat sementara. Akibatnya, mereka cenderung untuk tidak berupaya maksimal dalam mengambil pengalaman interaksi dengan masyarakat lokal ketika muncul hambatan-hambatan adaptasi. Pada prosesnya mereka akan membentuk wadah-wadah (enclaves) diantara mereka sendiri. Karena merupakan kumpulan dari orang yang berasal dari budaya pendatang yang sama, wadah-wadah seperti ini memang mampu mengurangi kecemasan dan rasa tidak berdaya akibat tekanan lingkungan asing tempat mereka belajar. Namun, dampak buruknya, mereka akan kehilangan kesempatan untuk mengembangkan diri melalui belajar secara langsung bagaimana hidup dengan masyarakat dari beragam budaya.

Salah satu dampak negatif dari kesulitan menyesuaikan diri dengan lingkungan baru adalah stress akulturasi. Stres akulturasi adalah serangkaian pengalaman psikologis yang kompleks, biasanya tidak menyenangkan dan menganggu (Tsytsarev \& Krichmar, dalam Shiraev \& Levy, 2012). Furnham \& Bochner (1986) menyatakan kondisi tersebut sebagai culture shock (gegar budaya) yang ditandai dengan munculnya rasa kehilangan, kebingungan tentang perannya, dan kecemasan yang berlebihan yang membuat individu menarik diri dari lingkungan sosialnya.

Maganga (2009) menyatakan bahwa stres akulturatif dapat dikurangi dengan bersikap positif terhadap masyarakat tuan rumah (host society). Bersikap positif tersebut dilakukan dengan cara mengambil keuntungan dari beberapa peluang yang 
tersedia ketika mereka berada di lingkungan baru. Salah satu kekurangan pendatang adalah tidak selalu memiliki mobilitas sehingga mereka gagal untuk menikmati pengalaman mereka sebagai pendatang. Selain itu, kemauan mereka untuk belajar berinteraksi dengan masyarakat lokal akan mengurangi stres akulturasi mereka. Apabila individu dapat mengatasi stress akulturasi, maka individu tersebut akan dapat menyesuaikan diri dengan baik yang pada gilirannnya akan mendatangkan kesejahteraan psikologis (well being) hingga memungkinkan tercapainya tujuan belajar yang optimal bagi para mahasiswa dari luar pulau Jawa.

Scheneiders (dalam Melda, 2008) menyatakan bahwa penyesuaian diri yang normal ditandai dengan tidak adanya emosi yang berlebihan sehingga membuat individu mampu menanggapi berbagai situasi atau masalah dengan emosi yang tenang dan terkontrol. Selain itu proses penyesuaian diri yang normal ditandai juga dengan sejumlah pertumbuhan atau perkembangan yang berhubungan dengan cara menyelesaikan situasi-situasi yang penuh konflik, frustasi dan ketegangan.

Ketika orang menghadapi permasalahan dalam penyesuaian diri, maka ia akan berupaya untuk mengatasinya. Lazarus (1976) mengemukakan cara-cara untuk menghilangkan stresor yang dihadapi, yaitu menghindari masalah yang dihadapinya (avoidance), mengevaluasi kembali masalah yang dihadapinya dengan pola pikir yang positif (distancing), mengatur perasaan dan tindakannya (self control) dan mengambil langkah aktif untuk mengatasi stresor (active coping). Penelitian ini bertujuan untuk mengetahui bagaimana pengalaman penyesuaian diri mahasiswa Papua yang sedang menjalani studi di pulau Jawa, khususnya di Universitas Negeri Surabaya dan strategi yang ditempuh untuk mengatasi masalah penyesuaian diri. Mahasiswa yang berasal dari Papua berpeluang menghadapi persoalan psikologis terkait problem adaptasi dengan masyarakat lokal tempat mereka belajar karena mereka memiliki perbedaan secara fisik, bahasa, dan kebiasaan budaya dengan mayoritas mahasiswa Jawa pada khususnya dan masyarakat Jawa di Surabaya pada umumnya.

\section{METODE}

\section{Partisipan}

Menurut Smith \& Eatough (2007) tidak terdapat adanya jawaban yang tepat atas pertanyaan berapa jumlah sampel yang dibutuhkan dalam penelitian fenomenologis dikarenakan jumlah subjek tergantung pada beberapa faktor yaitu: tingkat komitmen dalam analisis dan pelaporan, kekayaan data, dan kendala yang dihadapi. Namun, 5-6 partisipan terkadang direkomendasikan sebagai jumlah sampel yang wajar (Smith \& Eatough, 2007). Tujuh mahasiswa Papua berhasil direkrut untuk berpartisipasi dalam penelitian ini melalui teknik pusposive dan snowball sampling. Tujuh partisipan tersebut adalah (dalam nama samaran): Nuken (20 th), Paulus (19 th), dan Ketron (25 th) yang berasal dari Wamena. Mahasiswa lainnya adalah Thomas (21 th), Flora (19 th), Zam (21 th), dan Pilo (19 th) yang berasal dari Biak. Dua dari tujuh partisipan penelitian berjenis kelamin perempuan (Flora dan Pilo). Partisipan dipilih berdasarkan dua kriteria, yaitu berasal dari etnik asli Papua dan telah menempuh studi minimal 1 tahun di Universitas Negeri Surabaya (Unesa). Tujuh mahasiswa tersebut menempuh studi di beberapa fakultas di Unesa.

\section{Teknik Pengumpulan data}

Data dikumpulkan melalui wawancara mendalam semi-terstruktur. Teknik 
wawancara ini memungkinkan peneliti untuk dapat menyelidiki lebih jauh wawasan menarik dan penting yang muncul selama proses wawancara (Smith \& Eatough, 2007). Pedoman umum wawancara digunakan dalam penelitian ini namun tidak kaku dan dapat berubah seiring dengan penemuan data-data baru selama proses wawancara degan beberapa partisipan awal. Pedoman wawancara berisi dua puluh pertanyaan yang diawali dengan isu demografis tentang identitas dan latar belakang, dilanjutkan dengan pengalaman interaksi dengan masyarakat lokal, persepsi terhadap masyarakat lokal, dan kesulitan-kesulitan yang dihadapi. Wawancara diakhiri dengan pertanyaan tentang cara mengatasi kesulitankesulitan dalam interaksi. Wawancara dilakukan di beberapa tempat di area kampus yang tidak bisa didengar pihak ketiga, di asrama mahasiswa, dan tempat kos partisipan. Wawancara direkam menggunakan smartphone.

\section{Teknik Analisis Data}

Data dianalisis menggunakan interpretative phenomenological analysis (IPA). Menurut Smith \& Eatough (2007), IPA bertujuan mengungkap secara detail bagaimana partisipan memaknai dunia personal dan sosialnya. IPA memungkinkan peneliti mendapatkan pengalaman subjektif dan pemaknaan partisipan dalam melakukan penyesuaian diri. Proses analisis data dilakukan menggunakan langkah-langkah yang di usulkan oleh Smith \& Eatough (2007). Analisis diawali dengan mentranskrip hasil wawancara dan membaca setiap transkrip beberapa kali untuk memahami dan menghayati apa yang dirasakan partisipan. Transkrip yang telah dibaca berulang-ulang diberi komentar dan koding berupa catatan peneliti di lajur kiri. Catatan pada lajur kiri tersebut dilakukan sampai selesai membaca seluruh transkrip, kemudian catatan-catatan tersebut dimaknai kembali hingga mendapatkan kata-kata atau frase yang bersifat konseptual yang ditulis di margin kanan. Selanjutnya macam-macam kata atau frase konseptual di margin kanan tersebut dikelompokkan berdasarkan kesamaan makna dengan yang lain dan diberi label subtema. Semua subtema yang telah diidentifikasi kemudian dikelompokkan lagi berdasarkan kesamaan cakupannnya dan diberi label tema yang lebih besar atau superordinat theme. Proses akhir analisis data ini adalah diperolehnya sebuah tabel tema yang disertai dengan kutipan ekstrak-ekstrak wawancara. Berdasarkan tabel tema inilah kemudian dibuat laporan penelitian.

Penelitian ini menggunakan kriteria evaluasi dengan cara mendasarkan interpretasi peneliti pada contoh ekstrak wawancara yang dikutip. Menurut Elliot dkk (1999), cara ini disebut grounding in examples dimana penulis memberikan contoh dari ekstrak data yang digunakan dan dikembangkan berdasarkan pemahaman peneliti. Pengutipan ekstrak wawancara tersebut memungkinkan pembaca untuk menguji argumen atau persuasi peneliti dengan membandingkan dengan pemahamannnya sendiri. Peneliti menggunakan lambang '[ ... ]' dalam kutipan untuk menunjukkan adanya materi yang dihapus karena tidak relevan. Sedangkan kalimat dalam tanda kurung '( )' adalah klarifikasi makna dari peneliti atas data asli. Peneliti juga mengarsip semua data yang merupakan bukti dari laporan mulai dari catatan awal tentang proses perekrutan partisipan, pertanyaan penelitian, jadwal wawancara, rekaman, transkrip, proses pengkodingan, hingga tabel tema yang dihasilkan dapat ditelusuri jejaknya oleh pihak ketiga. Hal ini sebagai salah satu cara untuk menjamin transparansi proses penelitian. 


\section{HASIL PENELITIAN}

Penelitian ini berhasil mengidentifikasi empat tema utama, yaitu pengalaman penyesuaian diri, dampak penyesuaian diri, strategi penyesuaian diri, dan alasan-alasan penyesuaian diri.

\section{Tema : Pengalaman Penyesuaian Diri}

Ketika berada di pulau Jawa, sebagian besar partisipan merasakan banyaknya perbedaan lingkungan sosial yang membuat mereka tidak nyaman. Hal ini disebabkan adanya perbedaan bahasa dan cara berbicara. Perbedaan bahasa menyulitkan mereka untuk berinteraksi dengan masyarakat lokal.

Saya belum tahu apakah saya ngomong salah atau benar, makanya saya agak takut, begitu, jadi saya harus menyelesaikan semua, hafal semua bahasa disini. Nah saya baru bisa berani ngomong gitu(Nuken)

Kalau menurut aku tuh ya emang kita ngak tahu bahasa Jawa atau bahasa Jawa itu gimana, tapi itu membuat kita tersinggung kalau mereka berbicara tertawa. (Thomas)

Selain adanya kesalahpaman partisipan akan arti dari bahasa lokal, cara berbicara masyarakat lokal juga mengganggu partisipan. Seringkali partisipan merasa tersinggung apabila mereka mengetahui orang lain berbicara dengan bahasa Jawa sambil tertawa. Mereka merasa sedang menjadi bahan pembicaraan. $\mathrm{P}$ a $\mathrm{n} \mathrm{d}$ a $\mathrm{ng}$ a $\mathrm{n}$ mereka atas perlakuan mahasiswa dan masyarakat lokal yang cenderung merendahkan mereka juga menjadi faktor penghambat interaksi.

Bagi mereka kita orang asing lah. Selalu diketawain, diginiin [...] Katanya kita orang Papua itu jahat-jahat. (Thomas)

Kalau lewat gitu kan ditatap dari kaki sampai kepala wah jadinya kan malu toh jadinya apa ada yang salah di kita? Jadi dilihatnya begitu (Pilo)

Cara masyarakat memandang mereka membuat mereka merasa seperti orang asing. Mereka merasa dipandang secara berbeda, disalahpahami, dan kerap ditertawakan. Persepsi partisipan bahwa ada pemahaman masyarakat lokal yang keliru terhadap mereka sebagai orang Papua membuat partisipan semakin sulit untuk berinteraksi. Dalam pandangan partisipan, tidak semua masyarakat atau mahasiswa lokal siap untuk dekat dengan mereka.

Kalau kita diajak ngobrol kan bisa kenalan. Kita dari luar, jadi ya mereka ya tuan rumahnya gitu, jadi kalau mereka ajak ngobrol pasti kita ngobrol, berteman, tapi jarang. (Pilo)

[...] ada yang dia berani datang (untuk) kenalan, dia berani ajak omong, tanya [...] berani dia perkenalkan diri ya sudah jadi akrab. Terus ada yang lama sekali (untuk kenalan dengan kita). (Ketron)

[...] kalau menurut saya itu apakah tidak peduli dengan saya, apakah (saya) banyak kekurangan, atau gimana. (Nuken)

Kutipan wawancara di atas menunjukan bahwa partisipan sebenarnya menginginkan kedekatan hubungan dengan masyarakat lokal. Namun partisipan memandang ada kesalahpahaman dari masyarakat lokal yang menghalangi kedekatan. Tidak semua masyarakat lokal berani untuk dekat dengan partisipan secara langsung. Hal tersebut menyebabkan partisipan merasa bahwa masyarakat lokal barangkali memang cenderung tidak peduli atau justru meneguhkan kecurigaan awal mereka bahwa masyarakat lokal melihat ada sesuatu yang salah pada diri mahasiswa Papua ini.

Pengalaman interaksi yang kurang baik ini membuat sebagian partisipan menilai kebiasaan masyarakat lokal secara negatif. 
Kebanyakan tuh kadang kan egois memikirkan diri sendiri, kalau kita disana itu kalau orang punya uang atau suatu barang apapun itu untuk kita semua.(Nuken)

Orang sini lebih kalau bahasa Jawanya lebih kalem dan mereka tidak bisa menyalahkan kesalahan orang itu di depannya langsung jadi intinya tidak bisa menegur secara langsung. (Thomas)

Kalau orang sini kan ngomongnya cuma itu, tapi dia agak berputar sedikit baru masuk (ke inti persoalan). Saya baru-baru (ini) mengalami (seperti itu).(Ketron)

Disana itu tidak ada warung kopi [...] ini kok duduk lama gitu jadi bosen sekali gitu [...] buang uang saya pikir, kadang main waktu padahal kan mau kerja. (Nuken)

Sebagian besar partisipan menunjukkan bahwa mereka merasa tidak nyaman terhadap karakteristik masyarakat lokal. Orang lokal dianggap kalem oleh mayoritas partisipan. Bagi mereka, karakter kalem masyarakat lokal membuat masyarakat lokal tidak dapat berterus terang. Hal ini berbeda dengan orang Papua yang terbiasa mengungkapkan perasaannya secara terbuka. Partisipan juga mengaku tidak biasa dengan karakter masyarakat lokal yang cenderung individualistik. Berbeda dengan kebiasaan mereka yang mengedepankan kebersamaan. Para partisipan juga merasa masyarakat lokal suka membuang waktu dengan lebih suka di warung kopi. Hal itu berbeda dengan kebiasaan mereka untuk menyelesaikan pekerjaan secepatnya dan tidak suka menunda pekerjaan.

\section{Tema : Dampak Kesulitan Penyesuaian Diri}

\section{Dampak Personal}

Persepsi para partisipan yang kurang baik terhadap masyarakat lokal mempengaruhi cara pandang mereka terhadap diri mereka maupun dalam merespon permasalahan. Hal tersebut membuat mereka semakin merasa berjarak dari mahasiswa dan masyarakat lokal.

Kalau mau bergabung sama masyarakat Jawa disini terkadang kita minder, terus kurang percaya diri, merasa tidak cocok, merasa berbeda dengan mereka (Paulus)

Untuk masyarakat Jawa, "Tolong kalian pahami
keterbelakangan kami, terus cara tingkah kita
atau cara bicara kita, cara pemikiran kita yang di
belakang, mungkin beberapa langkah
dibelakang kalian". (Paulus)

Ya mungkin karena kulit kita hitam, ya mungkin bagi mereka kita orang asing. (Thomas)

Perbedaan fisik, logat bicara, dan kebiasaan para partisipan dengan masyarakat lokal dimaknai oleh partisipan sebagai penghambat interaksi sosial. Persepsi semacam itu mengakibatkan sebagian partisipan merasa rendah diri (inferior) ketika berhubungan dengan masyarakat lokal. Bahkan, Paulus tampak membutuhkan pengertian atau keinginan untuk dipahami oleh masyarakat lokal atas perbedaan yang ia miliki sebagai orang Papua.

Perasaan inferior tersebut membuat mereka tidak mendapatkan kenyamanan ketika menjalin kontak dengan masyarakat lokal.

[...] disaat ada orang berbicara yang menyinggung kita sedikit, walaupun sebenarnya itu canda tapi pembawaan kita ingin marah gitu (Paulus)

Apalagi pas kita lewat. Seperti apa ya apa bahasa tubuhnya kan ini gimana omong pakai bahaa Jawa sambil lirik begitu (Pilo)

Ketidakmampuan partisipan dalam memahami bahasa yang digunakan masyarakat lokal maupun cara komunikasi, disertai persepsi bahwa masyarakat lokal cenderung memandang mereka secara berbeda, membuat partisipan menjadi lebih 
sering menafsirkan bahasa non-verbal orang lokal sebagai serangan terhadap diri mereka.

\section{Dampak Sosial}

Dengan adanya berbagai kesulitan yang menghambat penyesuaian diri partisipan, kehidupan sosial sehari-hari mereka akhirnya menjadi lebih terbatas.

\begin{abstract}
Karena sampai sekarang pun saya belum pernah mendekati tetangga makanya saya juga meskipun dekat di sininya tapi sampai sekarang kan belum pernah (Nuken)
\end{abstract}

Kalau kita, kita tidak ada rasa memulai (untuk menyapa) melainkan mereka yang memulai [...] kalau menurut kita sih ya biasa aja tapi kalau mereka mungkin beranggapan nya lain (Paulus)

Kita jarang sekali sama yang lain kan, tidak bergaul dengan anak-anak teknik yang orang Jawa (Pilo)

Sebagian partisipan mengakui bahwa mereka kurang aktif dalam menjalin relasi dengan masyarakat sekitar. Mereka tidak cukup mencoba menjalin hubungan dengan mahasiswa dan masyarakat lokal yang ada di lingkungan sekitar mereka. Mereka lebih sering menunggu masyarakat atau mahasiswa lokal tersebut memulai pendekatan terlebih dahulu.

\section{Tema : Strategi Penyesuaian Diri}

Untuk menghadapi berbagai macam permasalahan adaptasi dan dampaknya tersebut, para partisipan menggunakan beberapa strategi, yaitu mengabaikan/ menghindari dari masalah (avoidance), mengatasi masalah secara aktif (active coping), dan mengatur emosi, pikiran dan tindakan (self control).

\section{Menghindar dari Masalah}

Hambatan komunikasi yang dialami para apartisipan sering menimbulkan kesalahpahaman. Strategi yang ditempuh oleh partisipan adalah dengan mengabaikan atau tidak peduli dengan sumber masalah.

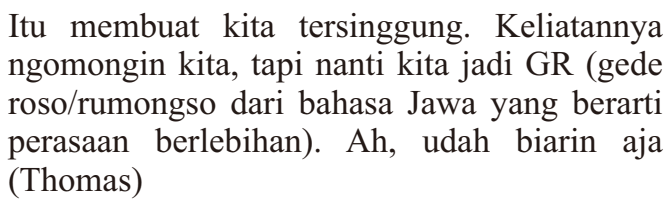
ngomongin kita, tapi nanti kita jadi GR (gede roso/rumongso dari bahasa Jawa yang berarti perasaan berlebihan). Ah, udah biarin aja (Thomas)

Yang penting jangan (sampai) saya tahu, kalau saya tahu nanti sakit hati [...]. Jadi ya sudah yang penting saya tidak mengerti. Ya sudah lanjut-lanjut aja kau omong. (Pilo)

Partisipan merespon kesalahpahaman ketika berinteraksi dengan mahasiswa lokal dengan tidak mempedulikannya. Hal ini dilakukan untuk menjaga rasa aman mereka. Selain itu, ketika partisipan mengalami perselisihan dengan mahasiswa lokal, mereka memilih untuk menahan diri dan mengalah. Hal ini mereka lakukan agar masalah yang terjadi tidak semakin besar dan menyulitkan mereka sebagai pendatang. Wawasan seperti ini bisa dilihat dari kutipan wawancara dari dua partisipan berikut:

Kita juga mau marah tapi kita kan merantau. Jadi mereka bilang apa, (kita) iya saja, setelah itu kita jabat tangan minta maaf untuk mereka, padahal kita kan tidak bersalah (Zam)

Yang pasti kecewa ya, kecewa itu pasti tapi ya gimana lagi? Istilahnya kita lagi menumpang kalau kita lagi numpang kita harus mengikuti peraturan dari tempat ini (Paulus)

Status mereka sebagai perantau membuat mereka mau tidak mau harus mengakui dan menerima norma dan kebiasaan masyarakat lokal. Hal ini mereka lakukan untuk menghindari permasalahan dalam interaksi dengan mahasiswa dan masyarakat lokal. Tekanan yang diakibatkan oleh permasalahan dalam interaksi dengan mahasiswa dan masyarakat lokal membuat partisipan cenderung mendekat pada 
kelompok mahasiswa sesama Papua untuk mendapatkan dukungan sosial dan emosional. Hal ini tampak pada kutipan wawancara dengan Paulus berikut:

Kadang kita kalau mau bergabung sama masyarakat Jawa disini terkadang kita minder terus kurang percaya diri, merasa tidak cocok merasa berbeda dengan mereka sehingga kita lebih memilih bergaul dengan anak-anak Papua yang menurut pandangan kita lebih mengerti tentang situasi yang kita miliki. (Paulus)

Namun, Paulus menyadari bahwa berhubungan hanya dengan sesama mahasiswa Papua dalam kehidupan seharihari selama studi di Jawa akan merugikan.

Kita terbiasa cuma pergaulan sesama Papua, kita terbatas dengan masyarakat Papua itu membuat kita semakin tidak secara leluasa tinggal di tempat ini karena di sini kita harus bergaul dengan masyarakat (Paulus)

\section{Kontrol Diri (self control)}

Strategi lain yang ditempuh para partisipan dalam menghadapi masalah dalam interaksi adalah kontrol diri, yaitu dengan mengatur emosi, pikiran, dan tindakan.

Saya rasanya mau saya bilang mau bunuh orang gitu, pingin pukul orang tapi kesabaran muncul gitu, jadi kadang gitu. (Nuken)

Kalau untuk mengatasinya harga matinya kita harus rela menyingkirkan dulu ego kita (Paulus)

Jangan terlalu tinggi pegang egomu karena egomu akan buat kamu susah sendiri disini karena kelangsungan hidup kamu disini ditentukan dengan bagaimana cara kamu menjalin hubungan dengan masyarakat disini (Paulus)

\section{Mengatasi Masalah Secara Aktif}

Partisipan lain melakukan respon secara aktif untuk mengatasi permasalahan penyesuaian diri. Seorang partisipan secara aktif mengingatkan mahasiswa lokal lawan bicaranya agar tidak menggunakan bahasa Jawa.

Mereka bicara kan pakai bahasa Jawa, biasa aku tegur mereka, kalau mau omong atau mau bicara dengan saya jangan pakai bahasa jawa soalnya saya tidak mengerti jadi pakai bahasa Indonesia yang baku aja. (Zam)

Partispan lainnya berupaya untuk mempelajari bahasa lokal (Jawa). Dengan mengerti bahasa lokal, mereka akan memahami apa yang masyarakat lokal katakan sehingga menjadi lebih mudah untuk bergaul dengan mereka.

Kita harus berjuang keras, yang pertama mungkin bahasa. (Paulus)

Dengan mengertinya bahasa daerah ini, saya lebih mudah untuk bergaul dengan masyarakat. (Paulus)

Selain itu, partisipan lainnya ikut secara aktif melakukan kegiatan bersama dengan mahasiswa lokal. Tindakan ini membuat mereka bisa bergaul dengan mahasiswa lokal.

Kalau pas lagi acara olahraga gitu pasti ramai lah, kita tegur, mereka tegur akhirnya kenal di situ. Terus ikut outbond. (Pilo)

Waktu dulu menyesuaikan diri disini ya mungkin lewat main futsal. (Thomas)

Ketika menghadapi permasalahan secara langsung ketika berhadapan dengan kondisi-kondisi yang membuat partisipan tidak nyaman, sebagian partisipan juga mengambil tindakan aktif dengan menyelesaikannya.

Kadang saya kirim facebook, kan ada grup, saya tulis “jangan tertawain karena kelemahan orang. Tapi kalau melakukan sesuatu harus berpikir maksudnya". Karena dia berbicara tuh harus berpikir jangan tertawa gitu (Nuken)

Aku pada waktu itu emosi, tapi aku berpikir bahwa aku sudah mahasiswa jadi tidak perlu 
mengambil keputusan seperti itu. Pastilah aku tegur gitu saja. (Thomas)

Partisipan bertindak aktif untuk mengurangi hambatan yang mempengaruhi emosi mereka dalam menyesuaikan diri. Partisipan lebih memilih untuk berkomunikasi dengan mahasiswa lokal tentang hal yang tidak mereka suka baik secara lisan maupun tertulis lewat sosial media.

\section{Tema : Alasan Melakukan Penyesuaian diri}

\section{Pengembangan diri}

Partisipan termotivasi untuk menyesuaikan diri karena kesadaran bahwa mereka saat ini sedang menempuh studi. Karena itu mereka tidak ingin hambatan dalam interaksi dengan mahasiswa lokal menghalangi mereka mendapatkan peluang untuk mengembangkan diri.

Supaya kita jadi guru kan belajar gitu kan, takutnya sampai di sana kita nggak tahu apaapa, untuk mengajar kan (perlu) mengerti budaya (lain). (Zam)

[...] kalau disana itu keberanian berbicara kurang, [...] sedangkan di sini berubah berani berbicara, iya itu menampilkan (diri) di depan orang gitu agak kaku gitu loh ngomongnya, mesti kurang lancar, tapi di sini ya agak bisa. (Nuken)

Pendidikan pemikiran kita kan masih terbatas, sampai di sini ya kita belajar di sini untuk meningkatkan pemikiran. (Zam)

Para partisipan tertantang untuk mengatasi kesulitan adaptasi dan bergaul dengan mahasiswa lokal agar dapat mengembangkan diri. Pengembangan diri ini akan menjadi bekal bagi mereka ketika kembali ke daerah asal untuk menjalankan perannya di sana.

\section{Menjaga kesejahteraan psikologis}

Selain untuk pengembangan diri, partisipan juga termotivasi untuk berinteraksi dan menyesuaikan diri dengan masyarakat dan mahasiswa lokal untuk menjaga rasa aman mereka.

\section{Supaya kan kalau kita menyesuaikan diri dan bergabung dengan mereka supaya kalau kita ada susah di mana atau jalan di mana mereka bisa (memberi) tahu. (Thomas)}

Biar punya teman banyak. Kita kan di rantauan. Kalau tidak punya teman, (saat) susah kan pasti bingung, tidak mungkin orang tua langsung datang. (Pilo)

Mayoritas partisipan sadar bahwa memiliki hubungan yang baik dengan masyarakat lokal penting bagi mereka. Mereka mengerti bahwa mereka membutuhkan teman untuk membantunya. Hal inilah yang membuat partisipan terdorong untuk menyesuaikan diri untuk lebih dapat diterima masyarakat lokal. Mereka menyadari bahwa dengan memiliki teman dekat dari masyarakat setempat, mereka dapat menjaga kesejahteraan psikologis mereka di tempat perantauan.

\section{PEMBAHASAN}

Hasil penelitian ini menunjukan bahwa ketika partisipan berada di Surabaya untuk menjalani kuliah, mereka merasakan berbagai macam kesulitan dalam berhubungan sosial dengan mahasiswa dan masyarakat lokal yang mayoritas beretnis Jawa. Penyebab utama dari kesulitan dalam berhubungan sosial itu adalah kendala bahasa dan perbedaan kebiasaan budaya. Hasil penelitian ini mendukung beberapa penelitian sebelumnya yang menghasilkan kesimpulan serupa, yakni perbedaan bahasa dan budaya merupakan kendala utama yang menghambat interaksi sosial antara mahasiswa pendatang dan 
mahasiswa atau masyarakat lokal tuan rumah (Sodjakusumah \& Everts, 1996; Niam, 2008; Maganga, 2009). Hasil penelitian ini juga seiring dengan beberapa hasil penelitian sebelumnya yang menyimpulkan bahwa bahwa bahasa menjadi penyebab gagalnya interaksi (Sicat, 2011; Pietila, 2010; Padila \& Perez, 2003).

Hambatan interaksi sosial yang dialami oleh mahasiswa Papua berdampak secara sosial maupun personal. Hampir setiap orang membutuhkan hubungan sosial dengan orang lain dan terpenuhi kebutuhannya untuk saling bertukar pesan secara bermakna agar terhindar dari rasa terisolasi (Porter \& Samovar, dalam Sihabudin, 2013). Dengan tidak dialaminya interaksi yang baik dengan mahasiswa dan masyarakat lokal, sebagian besar partisipan mengalami dampak sosial berupa kesalahpahaman. Partisipan menganggap bahwa masyarakat lokal memiliki kebiasaan dan kecenderungan karakter yang berbeda dengan mereka dalam sudut pandang yang cenderung negatif. Mahasiswa atau masyarakat lokal dipandang cenderung tidak peduli, individualistik, tidak terbuka dalam mengekspresikan sikap maupun perasaan, dan suka membuang waktu. Mereka memandang kebiasaan lawan bicaranya yang berasal dari Jawa untuk berbahasa Jawa merupakan salah satu bentuk ketidakpedulian mereka. Persepsi negatif ini akan merugikan karena menghalangi mereka untuk lebih dekat dengan masyarakat lokal (Berry dkk., 2006).

Para partisipan juga melaporkan bahwa mahasiswa dan masyarakat lokal cenderung memandang mereka secara negatif. Para partisipan mempersepsi bahwa perbedaan fisik dan warna kulit serta logat bahasa mereka sering menjadi sasaran perhatian dan pembicaraan. Persepsi ini membuat mereka merasa disikapi dan diperlakukan seperti orang asing. Tampaknya, wawasan dari partisipan ini sesuai dengan penelitian Padila
\& Perez (2003) yang menyatakan bahwa akulturasi akan lebih sulit pada orang-orang yang menghadapi stigma dalam perbedaan warna kulit dan bahasa. Sekalipun stigma warna kulit dan logat berbahasa ini belum dapat dipastikan dilakukan oleh mahasiswa dan masyarakat lokal yang mayoritas Jawa, hanya persepsi dan perasaan para partisipan bahwa mereka menjadi target stigma semacam itu saja sudah cukup untuk menghambat adanya interaksi sosial yang baik dengan masyarakat lokal.

Secara personal, dampak dari adanya hambatan dalam interaksi sosial ini adalah interaksi partisipan yang jarang dan berjarak dengan mahasiswa dan masyarakat lokal, yang pada akhirnya menimbulkan ketidaknyamanan dan kesulitan dalam beradaptasi (Lewthwite, 1996). Persepsi dan perasaan menjadi target dari pandangan negatif masyarakat lokal terkait perbedaan fisik, warna kulit, dan logat bahasa juga telah menimbulkan rasa inferior, malu, dan marah. Clemes (dalam Kusumawati, 2004) menyatakan bahwa individu yang memiliki perasaan inferioritas akan menghindari situasi yang menimbulkan rasa cemas, merasa orang lain tidak menghargainya, menyalahkan orang lain untuk kesalahannya sendiri, tidak percaya akan kemampuan dirinya, dan memiliki pemikiran negatif, sehingga membuat individu tersebut menarik diri dari lingkungan sosialnya. Karena itu, perasaan inferior para partisipan dapat menimbulkan perasaan sensitif yang timbul dari pemikiran negatif partisipan atas reaksi masyarakat lokal terhadap mereka. Hal ini ditunjukkan dari sikap partisipan yang mudah curiga dan marah. Salah satu contohnya adalah partisipan merasa tersinggung ketika mereka mengetahui masyarakat melirik mereka atau ketika berbicara sambil tertawa. Menurut Shiraev \& Boyd (dalam Shiraev \& Levy, 2012), kekurangan dan kesulitan berkomunikasi memang dapat menimbulkan 
frustasi dan perasaan terasing.

Kecenderungan para partisipan untuk melihat diri dan kebiasaannnya sebagai berbeda dengan mahasiswa dan masyarakat lokal daripada melihat kesamaannya, juga ikut memberi andil atas perasaan-perasaan negatif para partisipan. Seperti disimpulkan oleh Shiraev \& Boyd (dalam Shiraev \& Levy 2012), perbedaan budaya kebiasaan di lingkungan baru yang dilebih-lebihkan dengan kebiasaan budaya kampung halaman akan dapat menimbulkan gejala stres akulturatif. Stres akulturatif adalah serangkaian pengalaman psikologis yang kompleks biasanya tidak menyenangkan dan menganggu (Tsytsarev \& Krichmar, dalam Shiraev \& Levy, 2012). Stress akulturatif ini disebut juga sebagai culture shock (gegar budaya) yang ditandai dengan munculnya rasa kehilangan, kebingungan tentang peran, dan kecemasan yang berlebihan yang membuat individu menarik diri dari lingkungan sosialnya (Furnham \& Bochner, 1986). Berbagai emosi negatif akibat pengalaman interaksi yang buruk dengan mahasiswa dan masyarkat lokal yang dialami para partisipan pada tingkat tertentu menunjukkan mereka mengalami stress akulturatif ini.

Berbagai macam hambatan interaksi dan dampaknya tersebut membuat partisipan mencari strategi untuk menyelesaikan permasalahan-permasalahan yang mereka hadapi. Hal ini dilakukan para partisipan untuk mendapatkan keadaan stabil atau seimbang dalam dirinya (Shiraev \& Levy, 2012). Strategi untuk mengatasi masalah interaksi sosial dengan masyarakat lokal yang dilakukan para partisipan dapat dikategorikan menjadi 3 (tiga), yaitu mengabaikan atau menjauh dari masalah (avoidance), mengatur emosi, pikiran, dan sikapnya (self control), dan secara aktif menghadapi lansung permasalahan (active coping).

Para partisipan menghindar dari masalah ketika mereka menyadari apabila dihadapi langsung maka akan menimbulkan masalah yang lebih besar hingga lebih menyulitkan mereka. Mereka cenderung menghindar ketika berada dalam situasi yang menimbulkan perasaan inferior atau memicu kemarahan. Pengalaman dan perasaan emosi negatif para aprtisipan ketika berhubungan dengan anggota dari kelompok etnis tertentu (Jawa) sebagai masyarakat lokal mayoritas, menyebabkan munculnya prasangka terhadap semua anggota kelompok etnis tersebut (Shiraev \& Levy, 2012). Akhirnya, muncul keengganan pada para partisipan untuk memulai dan menjalin kontak secara dekat dengan masyarakat lokal dan cenderung lebih memilih berkumpul dengan kelompok asal partisipan. Kelompok sesama mahasiswa Papua memang dapat memberi dukungan sosial dan emosional pada para partisipan. Maganga (2009) mengemukakan bahwa dengan adanya kegagalan interaksi dengan masyarakat lokal yang berbeda, masyarakat pendatang akan membentuk wadah-wadah (forming enclaves) diantara mereka sendiri yang berfungsi mengurangi masalah dan rasa tidak berdaya akibat tekanan lingkungan sosial. Berry dkk. (2006) juga menyatakan bahwa pengalaman-pengalaman interaksi yang tidak menyenangkan seperti menjadi korban stereotip atau diskriminasi akan membuat masyarakat pendatang enggan untuk lebih dekat dengan masyarakat lokal dan membuat mereka lebih berfokus pada kelompok etnis mereka sendiri (Berry dkk., 2006). Namun, forming enclaves ini justru dapat memperkuat steorotip dari masyarakat lokal sehingga membuat masyarakat pendatang lebih sulit untuk berinteraksi (Maganga, 2009). Salah satu partisipan, misalnya, melaporkan bahwa dengan hanya bergaul dengan komunitas sesama mahasiswa Papua, ia merasa semakin tidak leluasa untuk bergaul dengan masyarakat lokal. Mengingat keberadaan mereka di pulau Jawa adalah 
untuk belajar, ketidakleluasaan untuk bergaul dengan mahasiswa dan masyarakat lokal ini dianggap sebagai membatasi peluang mereka untuk belajar lebih banyak sebagai bekal ketika mereka nanti kembali ke masyarakat asal.

Para partisipan menghadapi dilema antara memilih mendapatkan dukungan emosional dan sosial dari komunitas sesama mahasiswa Papua demi kenyamanan atau menghadapi perasaan tidak menyenangkan ketika berinteraksi dengan mahasiswa dan masyarakat lokal demi mendapatkan peluang untuk belajar dan mengembangkan diri. Dua strategi lain, yaitu self control dan active coping, yang diambil partisipan untuk mengatasi persoalan dalam interaksi dengan masyarakat lokal merupakan jawaban atas dilema ini.

Partisipan berupaya untuk meningkatkan self control mereka dengan menahan emosi, mencoba berpikir positif, dan, bahkan, siap meminta maaf terlebih dahulu ketika terjadi kesalahpahaman dengan mahasiswa lokal. Menurut Lazarus (1979) self control adalah strategi dimana individu berusaha untuk menabahkan diri dan tidak membiarkan perasaannya terlihat, serta menunjukkan usaha individu untuk mengatur perasaan dan tindakannya. Dengan melakukan kontrol diri, para partisipan dapat menjaga hubungan baik mereka dengan mahasiswa lokal. Kontrol diri tersebut juga menandakan bahwa partisipan cukup memiliki kemampuan penyesuaian diri karena tidak mudah menunjukkan emosi yang berlebihan (Scheneiders, dalam Melda, 2008).

Sebagian partisipan juga mencoba secara aktif menyelesaikan masalah dalam interaksi dengan mahasiswa dan masyarakat lokal dengan berupaya mempelajari bahasa lokal (Jawa). Mereka merasa dengan memahami bahasa lokal maka membuat mereka dapat lebih dekat dengan masyarakat dan meminimalkan kesalahpahaman yang terjadi. Hal ini sesuai dengan penelitian
Ruben \& Kealey (dalam Sihabudin 2011) yang menyatakan bahwa komunikasi menentukan kemampuan individu untuk berinteraksi secara kompeten dalam segala situasi kehidupan. Karena itu, belajar bahasa lokal sangat penting untuk menyesuaikan diri dengan lingkungan baru (Maganga, 2009). Sebagian partisipan juga menunjukkan bahwa mereka secara aktif melibatkan diri dalam berbagai kegiatan bersama seperti outbound dan olah raga agar dapat bergaul dengan mahasiswa lokal. Ketika mereka menghadapi persoalan akibat melibatkan diri dalam hubungan sosial dengan mahasiswa lokal, mereka juga siap mengatasinya secara langsung. Sebagai contoh, seorang partisipan mengatakan bahwa ia menegur temannnya agar menggunakan bahwa Indonesia ketika ia tidak mengerti bahasa Jawa yang digunakan temannya. Partisipan lainnya menggunakan media sosial untuk menunjukkan pada para temannya ketika mengalami situasi yang tidak menyenangkan dalam interaksi agar tidak terjadi kesalahpahaman.

Upaya para partisipan penelitian ini untuk mengatasi berbagai kesulitan dalam interaksi dengan mahasiswa dan masyarakat lokal menunjukkan kesiapan mereka untuk beradaptasi. Keinginan untuk mengembangkan diri dan mendapatkan kesejahteraan psikologis adalah dua motivasi utama yang mendorong para partisipan untuk mengambil beberapa strategi untuk menyelesaikan masalah dalam interaksi yang dapat meningkatkan upaya mereka untuk beradaptasi. Dengan kesuksesan dalam pergaulan sosial dengan mahasiswa dan masyarakat setempat, para partisipan optimis mereka akan dapat mengambil peluang untuk belajar apapun demi pengembangan diri. Mereka menyadari bahwa tempat studi mereka saat ini menawarkan banyak peluang untuk belajar. Kegagalan dalam interaksi sosial dengan mahasiswa dan masyarakat setempat hanya akan menghalangi tujuan 
utama mereka untuk belajar demi bekal nanti ketika telah kembali ke daerah asal. Sikap yang diambil ini merupakan sebuah langkah positif dalam beradaptasi dengan masyarakat lokal. Maganga (2009) menyatakan bahwa kemampuan untuk mengambil keuntungan dari peluang yang tersedia di lingkungan baru, merupakan sikap positif yang diperlukan untuk penyesuaian diri.

Selain pengembangan diri, upaya untuk menjaga kesejahteraan psikologis mereka juga mendasari dorongan untuk berupaya menyelesaikan persoalan interaksi dengan masyarakat lokal. Menurut Diener \& Oishi (2007), kesejahteraan psikologis muncul ketika seseorang mampu menerima kondisi diri, memiliki penguasaan diri, mengambil peluang pertumbuhan diri, dan memiliki komitmen atas suatu tujuan. Para partisipan bersikap positif dengan menunjukkan kesiapan untuk memahami dan menyesuaikan diri sesuai kemampuan mereka dengan kebiasaan masyarakat lokal agar dapat menempuh studi di perantauan dengan sukses.Para partisipan menyadari bahwa hidup di perantauan tidak selamanya bisa mengandalkan keluarga dan teman dekat sesama Papua. Mereka membutuhkan dukungan sosial dari teman-teman mahasiswa dan masyarakat lokal agar dapat menjalani studinya dengan mudah, nyaman, dan sejahtera.

\section{SIMPULAN}

Berdasarkan pembahasan hasil penelitian ini maka dapat disimpulkan bahwa mahasiswa luar pulau yang berasal dari Papua mengalami berbagai hambatan dalam menyesuaikan diri. Hambatan tersebut adalah adanya perbedaan bahasa, karak teristik fisik, dan kebiasaan budaya dengan masyarakat lokal. Hambatanhambatan tersebut memunculkan dampak psikologis dalam diri personal maupun kehidupan sosial mereka. Adanya hambatan dan dampak yang mereka alami membuat mereka melakukan strategi penyesuaian diri. Strategi penyesuaian diri yang diambil adalah menjauhi dari persoalan interaksi, meningkatkan kontrol diri, dan menghadapi masalah secara langsung. Strategi-strategi untuk mengatasi masalah interaksi sosial tersebut terutama didorong oleh dua motivasi, yaitu keinginan untuk menjaga kesejahteraan psikologis dan mencari peluang untuk pengembangan diri. Secara umum, meskipun para partisipan menghadapi berbagai kesulitan dalam berhubungan sosial dengan mahasiswa dan masyarakat lokal, mereka memahami bahwa berinteraksi secara dekat dengan mereka akan memberikan keuntungan, terutama untuk pengembangan diri.

\section{DAFTAR PUSTAKA}

Berry, J. W., Phinney, J. S., Sam, D. L., \& Vedder, P. (2006). Immigrant Youth: Acculturation, Identity, and Adaptation. Applied Psychology: An International Review, 55 (3), 303-332

Diener, E., Oishi, S., \& Lucas E. R. (2007). The optimal level of well-being: Can we be too happy? Perspectives on Psychological Science, 2, 346-360.

Elliot, R., Fiscer, Y., C., \& Rennie, L., D. (1999). Envolving Guidelines For Publication of Qualitative Research Studies In Psychology And Related Fields. British Journal of Clinical Psychology, 38, 215-229 
Furnham, A., \& Bochner, S. (1986). Culture Shock: Psychological Reactions for Unfamiliar Environments. London: Mathew \& Co. Ltd.

Lazarus, R.S. (1976). Patterns of Adjustment. New York: McGraw-Hill.

Lewthwaite, M. (1996). A Study of International Students' Perspectives of Cross-cultural Adaptation. International Journal for the Advancement of Counseling, 19, 167-185.

Maganga, S. M. (2009). An Antropological Study of The Experiences of Exchange Student In Port Elizabeth, South Africa. [Thesis]: Nelson Mandela Metropolitan University

Melda, S.S. (2008). Hubungan Antara Konsep Diri Dan Penyesuaian Diri Dengan Prestasi Belajar Pada Mahasiswa Baru Universitas Sumatra Utara. Skripsi: Universitas Sumatera Utara. Diakses dari ht tp://repository.usu.ac.id/ bitstream/123456789/23634. pada 20 juli 2012

Niam, E., K. (2009). Koping Terhadap Stress Pada Mahasiswa Luar Jawa Yang Mengalami Culture Shock di Universitas Muhammadiyah Surakarta. Indegenius: Jurnal Ilmiah Berkala Psikologi,11(1), 6977

Padila, A., \& Perez, W. (2003). Acculturation, Social Identity, and Social Cognition: A New Perspective. Hispanic Journal of Behavioral Sciences, 25(1), 35-55.

Papalia, D. E., Olds, S. W., \& Feldman, R. D. (2008). Human development: Psikologi Perkembangan. Edisi kesembilan. Jakarta: Kencana.

Pietila, I. (2010). Intercultural Adaptation as a
Dialogical Learning Proses : Motivational Factors Among the Short-term and Longterm migrants. Dissertation: University of $\mathrm{T}$ e m p e r e . D i a k s e s d a r i http://tampub.uta.fi/handle/10024/66616. pada 15 Mei 2012.

Pitopang, A. (2011). Filosofi Merantau: Kontribusi Perantau Untuk Memajukan Kampung Halaman. Diakses dari . Pada 15 Mei 2012

Shiraev, E. B., \& Levy, D. A., (2012). Psikologi Lintas Kultural: Pemikiran Kritis dan Terapan Modern. Edisi ke-4. Jakarta : Kencana

Sicat, R. M, (2011). Foreign Student Cultural Adjustment and Coping Strategies. International Proceedings of Economics Development and Research (IPEDR), 5, $338-341$. D i a k s e s d a r i http://www.ipedr.com/vo15/no2/74H10195.pdf pada 15 Mei 2012.

Sihabudin, A. (2011). Komunikasi Antarbudaya: Satu Perspektif Multidimensi. Jakarta: Bumi Aksara.

Smith, J. A. and Eatough, V. (2007). Interpretative Phenomenological Analysis. In E. Lyons And A. Coyle (Eds.). Analysing Qualitative Data in Psychology (pp. 35-50). London: Sage.

Sodjakusumah, I., T. \& Everts, H. (1996). Strangers In A Strange Land - Indonesian Students In New Zealand Universities And The Challenge In Pastoral Care. Paper presented at the ERA-AARE Conference, $\mathrm{S}$ i n g a pore. D i a k e s d a r i http://www.aare.edu.au/96 pap/ everh96344.txt. pada 15 Juli 2012. 